\title{
Effects of Timing of Ethofumesate Application on Severity of Gray Leaf Spot of Perennial Ryegrass Turf
}

\author{
W. Uddin and M. D. Soika, Department of Plant Pathology, and A. S. McNitt, Department of Crop and Soil Sci- \\ ences, The Pennsylvania State University, University Park 16802; and M. Fidanza, Division of Science, Berks- \\ Lehigh Valley College, The Pennsylvania State University, Reading 19610
}

\begin{abstract}
Uddin, W., Soika, M. D., McNitt, A. S., and Fidanza, M. 2004. Effects of timing of ethofumesate application on severity of gray leaf spot of perennial ryegrass turf. Plant Dis. 88:1146-1152.

Ethofumesate is a widely used herbicide for control of annual bluegrass (Poa апnиa) in perennial ryegrass (Lolium perenne) fairways on golf courses in the United States. Effect of timing of ethofumesate application on development of gray leaf spot was evaluated on perennial ryegrass turf treated with six classes of fungicide. Two applications of ethofumesate $(2.28 \mathrm{~kg}$ a.i./ha) were made to perennial ryegrass turf maintained at a $2-\mathrm{cm}$ height, at 4 -week intervals, each fall (October and November 1999 and 2000) or spring (April and May 2000 and 2001). In addition, turf was treated with the fungicides, azoxystrobin, chlorothalonil, flutolanil, iprodione, propiconazole, or thiophanate-methyl at the label rates at 14-day intervals. There were significant effects $(P \leq 0.05)$ of ethofumesate application timing and fungicide regime on gray leaf spot development. There also were significant interactions between the ethofumesate application timing and fungicide. Severity of gray leaf spot was significantly greater in turf plots treated with ethofumesate in spring compared to turf treated in fall or nontreated control plots treated with fungicides, flutolanil, iprodione, and propiconazole that were relatively less effective in control of gray leaf spot. There was no significant difference in disease severity in turf treated with ethofumesate in fall or to turf not treated with herbicide regardless of the fungicide used. Results of this study indicate that spring application of ethofumesate contributes to development of gray leaf spot epidemics, and the application timing interacts with the classes of fungicides. This study suggests that ethofumesate should be applied only in fall for control of $P$. апnиа, particularly in golf courses with a chronic gray leaf spot problem, as part of an integrated management of gray leaf spot in perennial ryegrass fairways.
\end{abstract}

Additional keywords: cultural practice, Magnaporthe grisea, weed control

Gray leaf spot of perennial ryegrass ( $L o$ lium perenne L.), caused by Pyricularia grisea (Cooke) Sacc., is a serious problem for the golf course industry in the United States. The disease was first reported on forage annual ryegrass (Lolium multiflorum Lam.) in the southern United States during the early 1970s, where severe outbreaks resulted in extensive loss of crop $(3,6)$. The disease then was referred to as blast because of the resemblance of foliar symptoms (leaf spot and blighting) to blast symptoms on rice $(3,33)$. However, in 1991, Landschoot and Hoyland (24) reported gray leaf spot on perennial ryegrass turf in golf course fairways in Pennsylvania. The epidemic was confined to the southeastern region of Pennsylvania,

Corresponding author W. Uddin

E-mail:wxu2@psu.edu

Financial support for this study was provided by the Golf Course Superintendent Association of America.

Accepted for publication 10 June 2004.

Publication no. D-2004-0805-01R

(C) 2004 The American Phytopathological Society where extensive damage was reported. Since this first report, outbreaks of gray leaf spot have occurred sporadically, resulting in serious loss of turf in 1995, 1998, and 2000 in the mid-Atlantic region $(9,34)$. The disease recently has been reported from the Midwest $(15,28,41)$, New England (29), and the western United States (38).

Gray leaf spot is favored by warm, wet, and humid conditions during late summer. Severe outbreaks of the disease occur during periods of moderately warm temperature, extended leaf wetness period, and high relative humidity $(35,39)$. Under favorable conditions, the disease develops rapidly, and entire ryegrass swards can be killed within a few days, leaving only annual bluegrass and other grassy weeds that are not affected by the disease. Since gray leaf spot was first detected on perennial ryegrass in 1991, the disease has resulted in increased annual fungicide costs of $\$ 20,000$ to $\$ 25,000$ on golf courses with perennial ryegrass fairways, and some resorts have reported losses of up to $\$ 500,000$ in revenue due to severe outbreaks of the disease (39). Fungicides used for control of gray leaf spot include chlorothalonil, strobilurin, thiophanate-methyl, tridimefon, and mancozeb (39).

Despite high susceptibility to $P$. grisea by perennial ryegrass, it remains a desirable grass species for fairway turf on golf courses because of the superior agronomic characters, such as winter hardiness, rapid germination and establishment, contrasting color with creeping bentgrass in putting greens, less thatch accumulation, and good playability for golfers due to upright growth and canopy density (26). Employing appropriate cultural practices in the management of high-quality perennial ryegrass turf is important; however, practices such as fertility management $(37,40,43)$, mowing height (43), and clipping management $(40,43)$ have been shown to influence development of gray leaf spot epidemic. Annual bluegrass is a serious weed on golf courses that is not affected by gray leaf spot. It proliferates effectively in bare areas in fairways that result from gray leaf spot epidemics (39). Control of annual bluegrass on golf courses is achieved chiefly by chemical means, particularly application of ethofumesate (2-ethoxy-2,3-dihydro-3,3-dimethyl-5-benzofuranyl methanesulfonate). It is labeled for established perennial ryegrass turf from early fall to late spring, one to three applications each season. In golf turf management, ethofumesate generally is applied in fall in most regions of the United States; however, the herbicide also is used in spring on many golf courses where infestation by annual bluegrass is severe. The label stipulates application of ethofumesate up to 30 days after annual bluegrass emergence in late spring in established perennial ryegrass turf. Although perennial ryegrass has relatively high tolerance to the herbicide $(7,8,12)$, it is unclear whether ethofumesate influences the development of gray leaf spot of perennial ryegrass turf. Additionally, it is not known whether timing of application of ethofumesate interacts with fungicides. Therefore, this study was undertaken to determine the effects of ethofumesate application on development gray leaf spot in turf maintained under various fungicide regimes.

\section{MATERIALS AND METHODS}

Maintenance of field plots. The field study was conducted at the Willow Hollow Golf Course, Leesport, PA, on Pennfine perennial ryegrass maintained as a golf 
course fairway, mowed three times per week at a 2-cm cutting height. The soil was a Duffield clay loam with $\mathrm{pH}$ 5.2. The experiments were conducted from October 1999 to September 2000, and October 2000 to October 2001. Each year, the fairway in which the experiment was conducted was treated with dithiopyr (Dimension 1EC; Dow Agrosciences, Philadelphia, PA) at the rate of $0.57 \mathrm{~kg}$ a.i./ha in spring (April) for control of crabgrass; and trinexapec-ethyl (Primo 1EC; Novartis Crop Protection, Inc., Greensboro, NC) as a growth regulator at the rate of $0.29 \mathrm{~kg}$ a.i./ha in order to reduce the mowing frequency and clipping yield. Additionally, the test area was fertilized (21-3-14) with $58 \mathrm{~kg}$ of N/ha twice (May and September) a year. Imidacloprid (Merit 75WP; Bayer Environmental Science, Montvale, NJ) was applied at $0.34 \mathrm{~kg}$ a.i./ha in May of each year for control of soil-inhabiting insect pests of turfgrass. A preventive application of mefenoxam (Subdue Maxx; Syngenta Crop Protection, Inc., Greensboro, NC) at $1.60 \mathrm{~kg}$ a.i./ha was made in July of each year for control of Pythium foliar blight. These management practices were carried out by the golf course superintendent as part of the routine maintenance of the fairways in the golf course.

Application of herbicide and fungicide treatments. The experiment was conducted at Willow Hollow Golf Course from October 1999 to September 2000, and repeated at the same golf course from October 2000 to October 2001. Treatments were arranged as a split-plot design, where fungicide class was the main-plot factor and the herbicide application timing was the subplot factor. There were four treatment replications, and the main plots were 0.9 by $5.5 \mathrm{~m}$ and subplots were 0.5 by 2.8 $\mathrm{m}$. The fungicide treatments included chlorothalonil (Daconil Ultrex at $9.58 \mathrm{~kg}$ a.i./ha; Zeneca Professional Products, Wilmington, DE), propiconazole (Banner Maxx at $0.94 \mathrm{~kg}$ a.i./ha; Novartis Crop Protection), thiophanate-methyl (Cleary's 3336 at $9.11 \mathrm{~kg}$ a.i./ha; W. A. Cleary Chemical Corporation, Somerset, NJ), iprodione (Chipco 26GT at $4.57 \mathrm{~kg}$ a.i./ha; Bayer Environmental Science, Research Triangle Park, NC), flutolanil (ProStar at $4.59 \mathrm{~kg}$ a.i./ha; Bayer Environmental Science), and azoxystrobin (Heritage at 0.61 $\mathrm{kg}$ a.i./ha; Syngenta Crop Protection). The herbicide treatments include application of ethofumesate (Prograss; Bayer Environmental Science) treatments at the label rate of $2.28 \mathrm{~kg}$ a.i./ha each in fall or spring. Control plots for main-plot and subplot factors were not sprayed. In the 1999-2000 season, application of ethofumesate was made twice each in fall (6 October and 3 November 1999) and spring (26 April and 24 May 2000). Applications of the fungicide were initiated on 19 July 2003 and continued at 14-day intervals, except for azoxystrobin applied at 28-day intervals through 13 September 2000. Fungicides were applied with a handheld boom sprayer equipped with TeeJet 8004 flat fan nozzles (Spraying Systems Co., Wheaton, IL), powered with $\mathrm{CO}_{2}$ at $40 \mathrm{psi}$, and delivered in water equivalent to 7.6 liters per $93 \mathrm{~m}^{2}$.

On 18 August 2000, the experimental turf area was inoculated with aqueous suspension of a monoconidial isolate of $P$. grisea (approximately $11 \times 10^{3}$ conidia $/ \mathrm{ml}$ of distilled water) that was isolated from leaf blades from blighted turf area in fairways at Willow Hollow Golf Course in September 1998. Inoculation of the plants was conducted by applying the conidial suspension to the turf area with a $\mathrm{CO}_{2}$-powered sprayer using a TeeJet $11008 \mathrm{E}$ nozzle at $40 \mathrm{psi}$, in water equivalent to 7.6 liters per $93 \mathrm{~m}^{2}$ Gray leaf spot severity (index 0 to 10 , where $0=$ turf asymptomatic and 10 $=>90 \%$ turf area blighted) was assessed visually at approximately 7-day intervals in the inoculated turf areas on the fairways from 23 August 2000 to 27 September 2000.
The experiment was repeated in the 2000-01 season at the Willow Hollow Golf Course on a turf area approximately $15 \mathrm{~m}$ from that used in 1999-2000. The experimental design and treatments were the same as that of the previous year. Ethofumesate treatments were applied in fall or spring, and the control plots for main-plot and subplot factors were not sprayed. Application of ethofumesate at the label rate of $2.28 \mathrm{~kg}$ a.i./ha was made twice each in fall (11 October and 8 November 2000) and spring (25 April and 23 May 2001). Applications of fungicides were initiated on 17 July 2001 and continued at 14 dayintervals, except for azoxystrobin, which as applied at 28-day intervals through 25 September 2001. Final application of azoxystrobin was made on 11 September 2001. Fungicides were applied with the handheld boom sprayer used in 19992000, following the procedure described previously.

Table 1. Analysis of the variance of the effects of fungicide (F) and timing of herbicide (HT) application on severity of gray leaf spot of perennial ryegrass turf

\begin{tabular}{|c|c|c|c|c|c|c|c|}
\hline \multicolumn{4}{|c|}{ Experiment 1} & \multicolumn{4}{|c|}{ Experiment 2} \\
\hline Source $^{\mathbf{a}}$ & df & MS & $P$ & Source & df & MS & $P$ \\
\hline 23 Aug & & & & $21 \mathrm{Aug}$ & & & \\
\hline $\mathrm{F}$ & 6 & 0.1786 & 0.0383 & $\mathrm{~F}$ & 6 & 4.4167 & 0.0001 \\
\hline HT & 2 & 0.2500 & 0.0063 & HT & 2 & 1.3214 & 0.0073 \\
\hline $\mathrm{F} \times \mathrm{HT}$ & 12 & 0.0833 & 0.0611 & $\mathrm{~F} \times \mathrm{HT}$ & 12 & 0.4464 & 0.0665 \\
\hline Error & 42 & $\ldots$ & $\ldots$ & Error & 42 & $\ldots$ & $\ldots$ \\
\hline 30 Aug & & & & 28 Aug & & & \\
\hline $\mathrm{F}$ & 6 & 7.5794 & 0.0001 & $\mathrm{~F}$ & 6 & 27.5198 & 0.0001 \\
\hline HT & 2 & 4.5119 & 0.0023 & HT & 2 & 19.0833 & 0.0001 \\
\hline $\mathrm{F} \times \mathrm{HT}$ & 12 & 0.9008 & 0.1996 & $\mathrm{~F} \times \mathrm{HT}$ & 12 & 2.0556 & 0.0001 \\
\hline Error & 42 & $\ldots$ & $\ldots$ & Error & 42 & $\ldots$ & $\ldots$ \\
\hline $6 \mathrm{Sep}$ & & & & 4 Sep & & & \\
\hline $\mathrm{F}$ & 6 & 46.5476 & 0.0001 & $\mathrm{~F}$ & 6 & 41.4127 & 0.0001 \\
\hline HT & 2 & 10.8571 & 0.0001 & HT & 2 & 23.2500 & 0.0001 \\
\hline $\mathrm{F} \times \mathrm{HT}$ & 12 & 1.3988 & 0.0001 & $\mathrm{~F} \times \mathrm{HT}$ & 12 & 1.2639 & 0.0041 \\
\hline Error & 42 & $\ldots$ & $\ldots$ & Error & 42 & $\ldots$ & $\ldots$ \\
\hline $13 \mathrm{Sep}$ & & & & $11 \mathrm{Sep}$ & & & \\
\hline $\mathrm{F}$ & 6 & 79.5952 & 0.0001 & $\mathrm{~F}$ & 6 & 54.4921 & 0.0001 \\
\hline HT & 2 & 16.0833 & 0.0001 & HT & 2 & 23.7619 & 0.0001 \\
\hline $\mathrm{F} \times \mathrm{HT}$ & 12 & 1.3750 & 0.0245 & $\mathrm{~F} \times \mathrm{HT}$ & 12 & 0.9980 & 0.2019 \\
\hline Error & 42 & $\ldots$ & $\ldots$ & Error & 42 & $\ldots$ & $\ldots$ \\
\hline $20 \mathrm{Sep}$ & & & & $18 \mathrm{Sep}$ & & & \\
\hline $\mathrm{F}$ & 6 & 92.8889 & 0.0001 & $\mathrm{~F}$ & 6 & 54.6071 & 0.0001 \\
\hline HT & 2 & 20.1548 & 0.0001 & HT & 2 & 24.6786 & 0.0001 \\
\hline $\mathrm{F} \times \mathrm{HT}$ & 12 & 1.6687 & 0.0006 & $\mathrm{~F} \times \mathrm{HT}$ & 12 & 1.4286 & 0.1375 \\
\hline Error & 42 & $\ldots$ & $\ldots$ & Error & 42 & $\ldots$ & $\ldots$ \\
\hline $27 \mathrm{Sep}$ & & & & $25 \mathrm{Sep}$ & & & \\
\hline $\mathrm{F}$ & 6 & 90.9444 & 0.0001 & $\mathrm{~F}$ & 6 & 70.4286 & 0.0001 \\
\hline HT & 2 & 10.0119 & 0.0001 & HT & 2 & 28.5833 & 0.0001 \\
\hline $\mathrm{F} \times \mathrm{HT}$ & 12 & 1.2063 & 0.0644 & $\mathrm{~F} \times \mathrm{HT}$ & 12 & 0.8333 & 0.3238 \\
\hline $\begin{array}{l}\text { Error } \\
4 \text { Oct }^{b}\end{array}$ & 42 & $\ldots$ & $\ldots$ & $\begin{array}{l}\text { Error } \\
2 \text { Oct }\end{array}$ & 42 & $\cdots$ & $\ldots$ \\
\hline$\ldots$ & $\ldots$ & $\ldots$ & $\ldots$ & $\mathrm{F}$ & 6 & 70.2063 & 0.0001 \\
\hline$\ldots$ & $\ldots$ & $\ldots$ & $\ldots$ & HT & 2 & 19.0119 & 0.0001 \\
\hline$\ldots$ & $\ldots$ & $\ldots$ & $\ldots$ & $\mathrm{F} \times \mathrm{HT}$ & 12 & 1.1230 & 0.0515 \\
\hline$\ldots$ & $\ldots$ & $\ldots$ & $\ldots$ & Error & 42 & $\ldots$ & $\ldots$ \\
\hline AUDPC $^{c}$ & & & & AUDPC & & & \\
\hline $\mathrm{F}$ & 6 & $1,073.5417$ & 0.0001 & $\mathrm{~F}$ & 6 & $1,553.83393$ & 0.0001 \\
\hline HT & 2 & 243.7708 & 0.0001 & HT & 2 & 729.0744 & 0.0001 \\
\hline $\mathrm{F} \times \mathrm{HT}$ & 12 & 21.3854 & 0.0001 & $\mathrm{~F} \times \mathrm{HT}$ & 12 & 29.8973 & 0.0049 \\
\hline Error & 42 & $\ldots$ & $\ldots$ & Error & 42 & $\ldots$ & $\ldots$ \\
\hline
\end{tabular}

${ }^{\mathrm{a}} \mathrm{F}$ = fungicides: flutolanil, iprodione, propiconazole, thiophanate-methyl, chlorothalonil, and azoxystrobin; HT = timing of herbicide (ethofumesate) application: fall or spring.

${ }^{\mathrm{b}}$ Disease assessment discontinued.

${ }^{c}$ AUDPC $=$ area under the disease progress curve (severity-weeks) computed from disease severity (index 0 to 10 , where $0=$ turf asymptomatic and $10=>90 \%$ turf area symptomatic). 
On 16 August 2001, the experimental turf area was inoculated with an aqueous conidial suspension of the same isolate of $P$. grisea (approximately $11 \times 10^{3}$ conidia/ml of distilled water) that was used previously. Development of gray leaf spot in the inoculated turf areas on the fairways was monitored from 21 August 2001 to 2 October 2001, and disease severity was evaluated as described previously.
Data analysis. Gray leaf spot severity data were subjected to analysis of variance using the SAS General Linear Model procedure to determine the effects of fungicide and timing of ethofumesate applica-
A

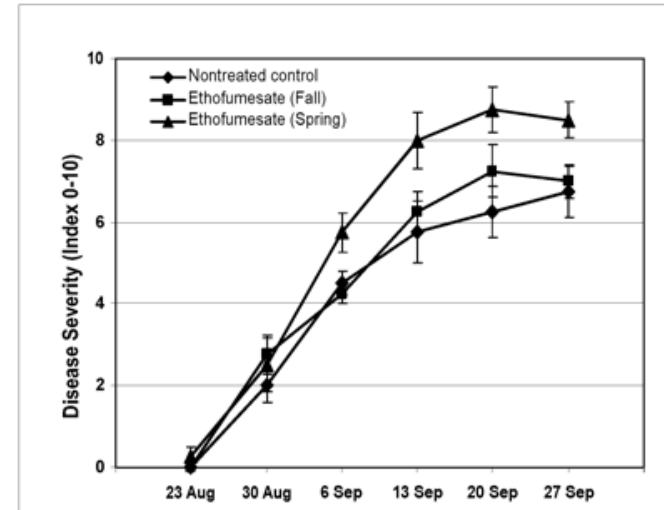

C

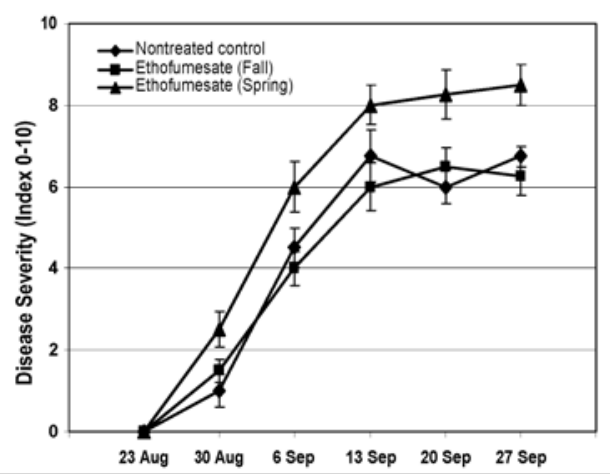

E

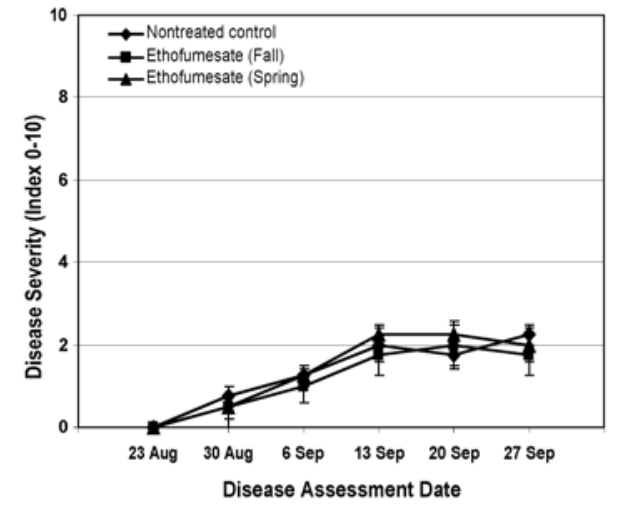

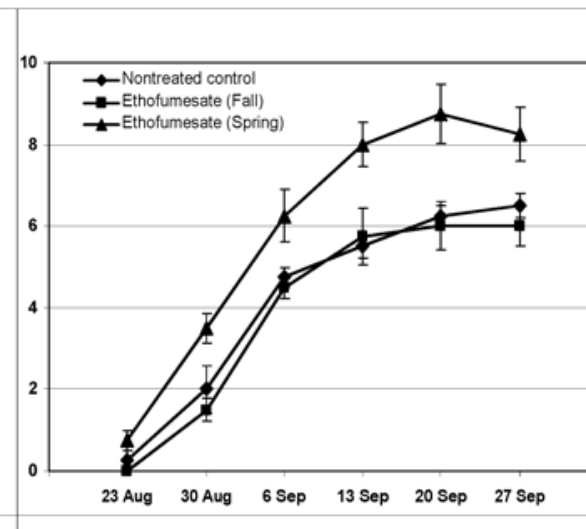

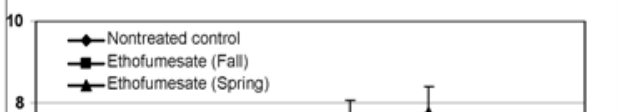

D

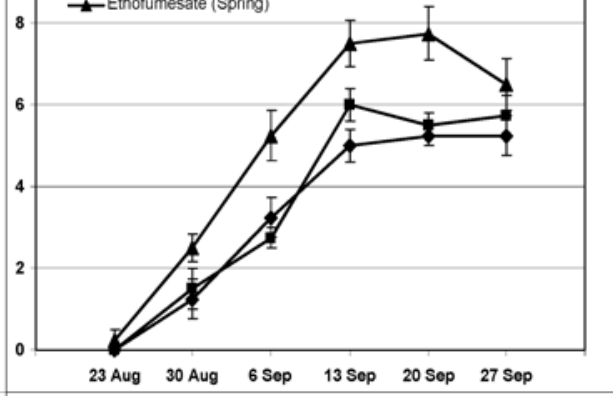

23 Aug 30 Aug 6 Sop 13 Sop 20 Sop 27 Sop

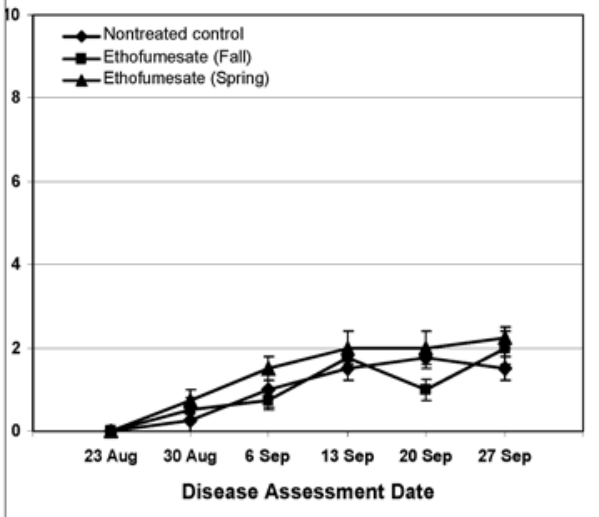

G

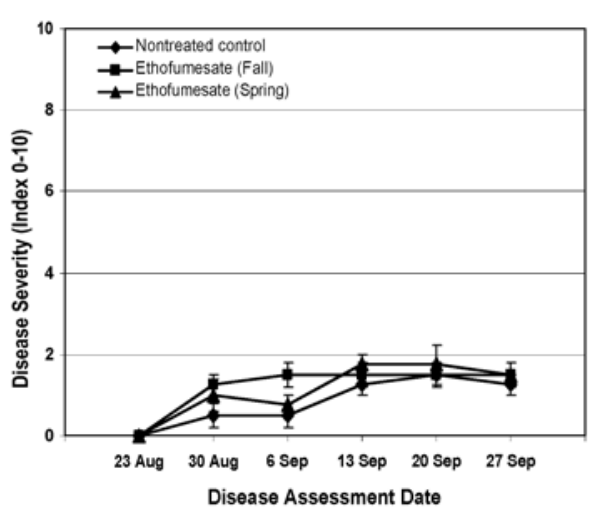

Fig. 1. Effects of timing of ethofumesate application on severity of gray leaf spot of perennial ryegrass turf treated with fungicide in 2000 . A, Nontreated control, B, flutolanil, C, iprodione, D, propiconazole, E, thiophanate-methyl, F, chlorothalonil, and G, azoxystrobin. (Experiment 1). 
tion on gray leaf spot severity. Area under the disease progress curve (AUDPC) was computed and the mean AUDPC values (severity-week) for the ethofumesate treatments within each fungicide were compared using the Student-Newman-Keuls test. All the statistical procedure were performed using SAS (version 8.1; Statistical Analysis System, Cary, NC).

\section{RESULTS}

Effects of timing of herbicide application and fungicide. In 2000 (experiment $1)$, there were significant effects $(P \leq 0.05)$ of herbicide application timing and fungicide regime on severity of gray leaf spot on all disease assessment dates (Table 1). Additionally, there were significant interactions between the herbicide application timing and fungicide treatment on three of the six assessment dates. Disease severity was relatively high in turf treated with flutolanil, iprodione, propiconazole, or no fungicide, and was relatively low in turf treated with thiophanate-methyl, chorothalonil, and azoxystrobin during the major period of gray leaf spot epidemic (Fig. 1).

Gray leaf spot was first evident on 23 August 2000 in spring-applied ethofumesate plots that were treated with flutolanil, propiconazole, or no fungicide. On 30 August 2000, the disease was significantly more severe in spring-applied ethofumesate plots than in the fall-applied plots, which were treated with flutolanil; however, there was no significant difference in disease severity between the fall-applied ethofumesate plots and the nontreated control. A similar effect of spring-applied ethofumesate was observed on 6, 13, and 20 September 2000 in plots treated with iporodione, propiconazole, or no fungicide, but not in plots treated with thiophanate-methyl, chlorothalonil, or azoxystobin. On 27 September 2000, there were no significant differences in disease severity among the ethofumesate-treated plots that were treated with fungicides other than flutolanil and iprodione in which disease in ethofumesate-treated plots in spring was significantly more severe than those treated in fall or the nontreated control. However, there were no significant differences in disease severity between fall-applied ethofumesate plots and the nontreated control. Analysis of the AUDPC values also showed a similar pattern of the effect of herbicide application timing on gray leaf spot development under the various fungicide regimes (Fig. 2). AUDPC for spring-applied ethofumesate plots was significantly higher than for the fall-applied plots or nontreated control that were treated with flutolanil, iprodione, propiconazole, or no fungicide; however, there were no significant differences between the AUDPC for fall-applied ethofumesate plots and nontreated control in these fungicide plots. There were no sig- nificant differences among the AUDPCs for ethofumesate-treated plots in fall, spring, and the nontreated control that were treated with thiophanate-methyl, chlorothalonil, and azoxystrobin.

The effects of timing of herbicide application and fungicide on gray leaf spot development followed a similar pattern when the experiment was repeated in 2001 (experiment 2). However, the disease was less severe in 2001 than that in 2000 (Fig. 2). In 2001, there were significant effects $(P \leq 0.05)$ of herbicide application timing and fungicide treatment on disease severity on all disease assessment dates (Table 1). Additionally, there were significant interactions between the herbicide application timing and fungicide regime on four of the
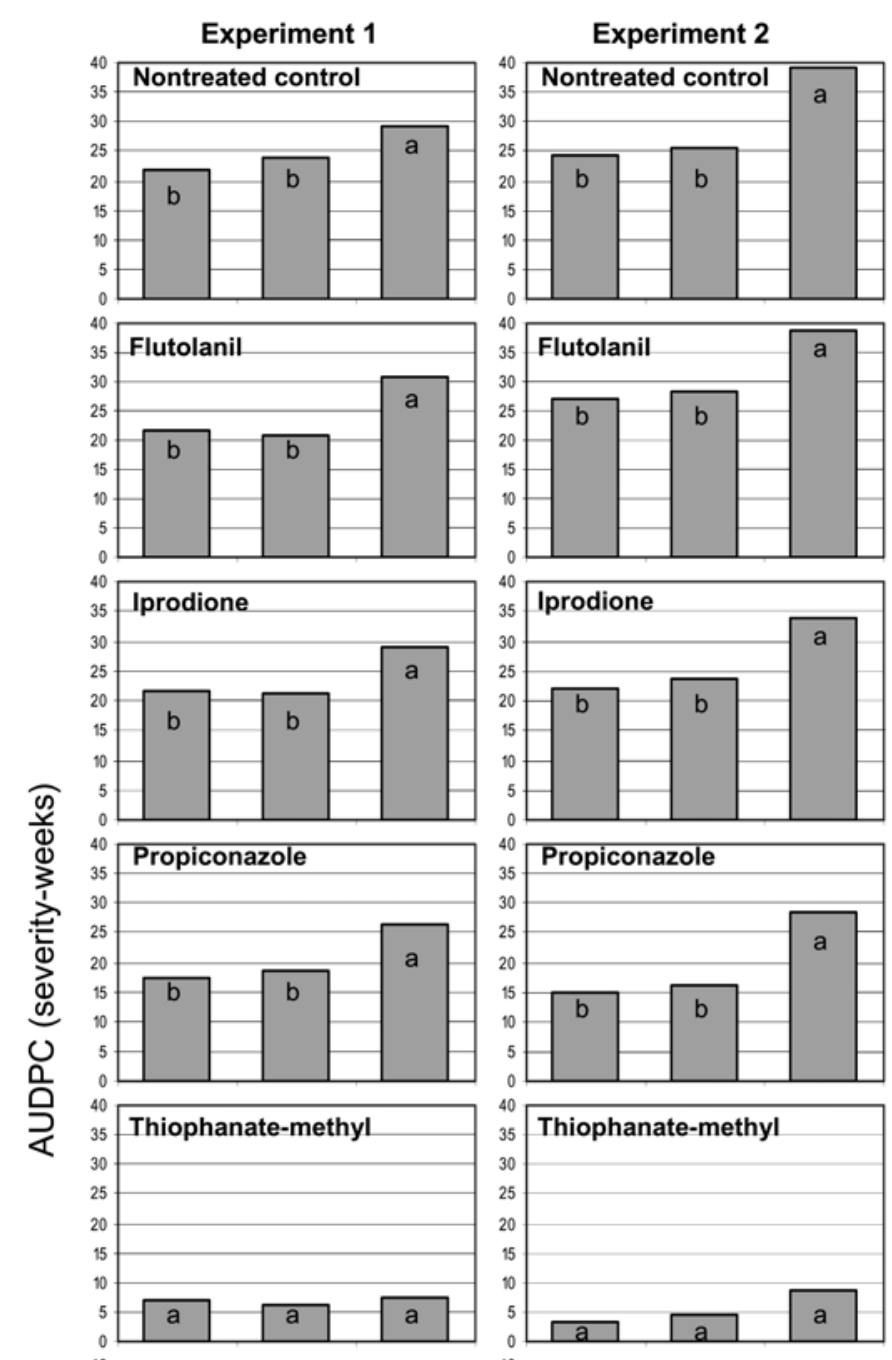

(n)

.


seven assessment dates. Gray leaf spot was significantly more severe in fall- or springapplied ethofumesate plots or the nontreated control that were treated with flutolanil, iprodione, propiconazole, or no fungicide compared with plots treated with thiophanate-methyl, chorothalonil, or azoxystrobin from 28 August to 2 October 2001 (Fig. 3). Gray leaf spot was first observed on 21 August 2000 in fall- or spring-applied ethofumesate plots and nontreated controls that were treated with propiconazole, iprodione, or no fungicide. In the first assessment, disease severity in spring-applied ethofumesate plots was significantly higher than the fall-applied or nontreated control plots that were treated with propiconazole. On 28 August 2001, gray leaf spot was observed in all herbicide and fungicide treatment plots and there were significant effects of ethofumesate application timing and fungicide on dis- ease severity. Additionally, there were interactions between ethofumesate application timing and fungicide. On 28 August 2001, disease severity in spring-applied ethofumesate plots was significantly higher than in fall-applied or nontreated control plots treated with flutolanil, propiconazole, or no fungicide. Effects of timing of herbicide under various fungicide treatments followed a similar pattern during the subsequent disease assessments.
A

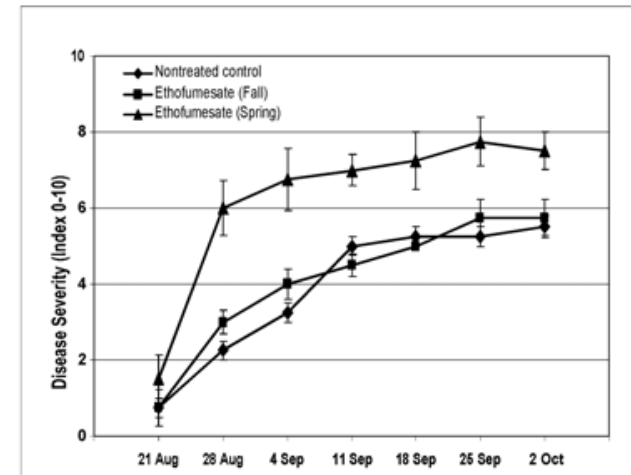

C

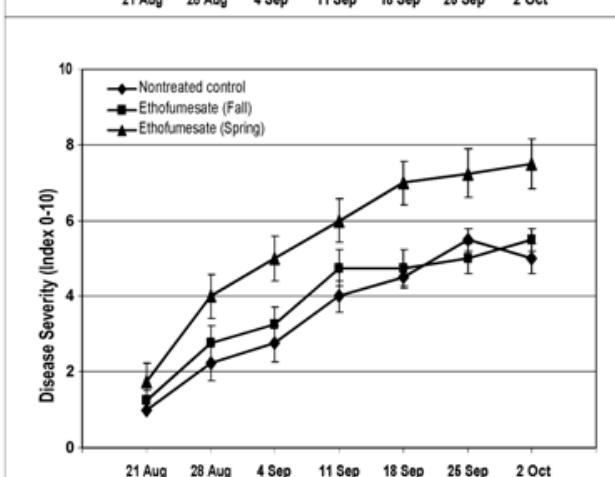

E

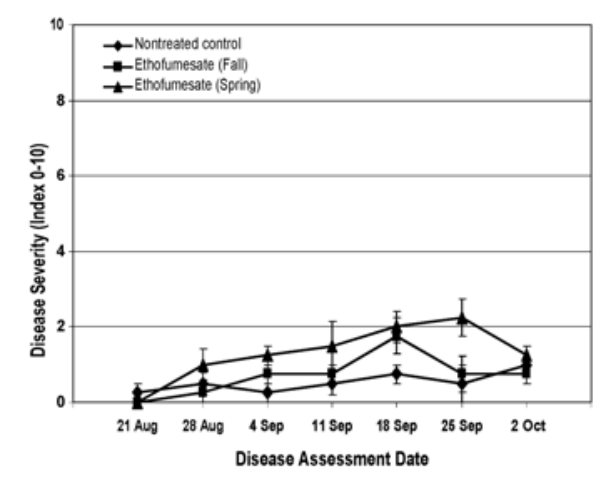

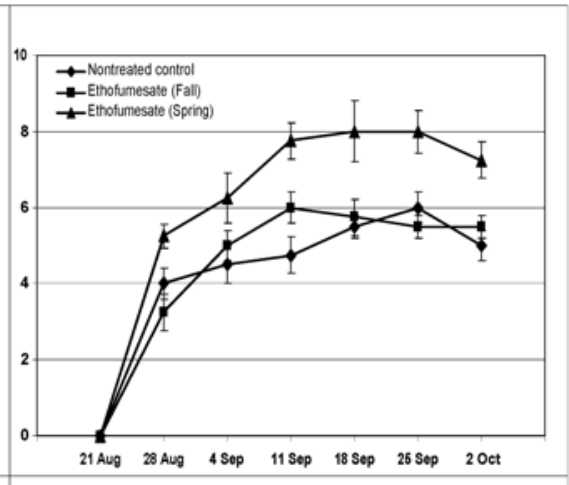
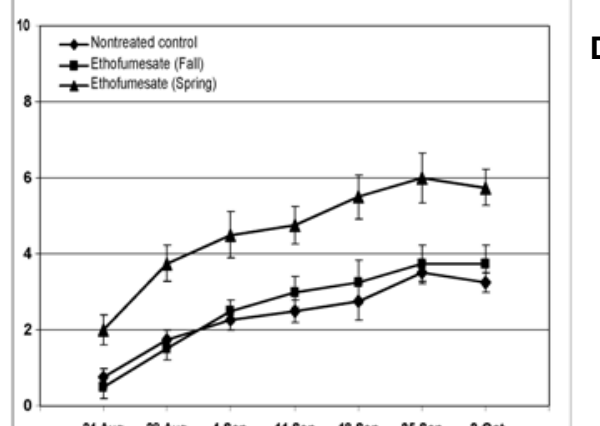

21 Aug 28 Aug 4 Sep 11 Sop 18 Sep 25 Sep 2 Oct

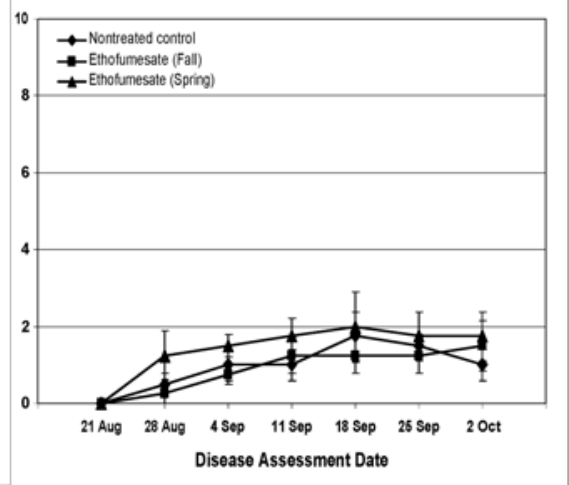

B

D

$\mathbf{F}$

G

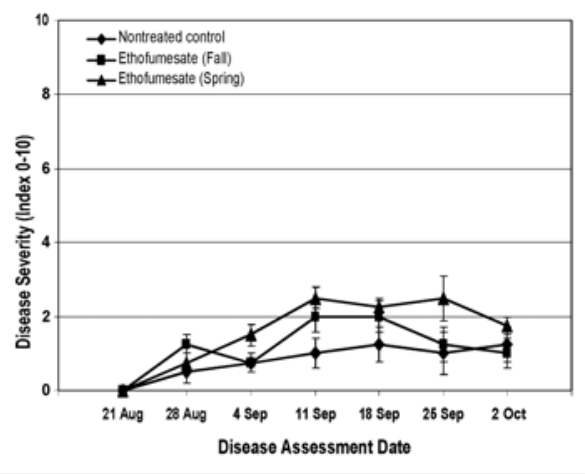

Fig. 3. Effects of timing of ethofumesate application on severity of gray leaf spot of perennial ryegrass turf treated with fungicide in 2001. A, Nontreated control, B, flutolanil, C, iprodione, D, propiconazole, E, thiophanate-methyl, F, chlorothalonil, and G, azoxystrobin. (Experiment 2). 
Analysis of AUDPC also showed a similar effect of herbicide application timing on gray leaf spot development under various fungicide regimes (Fig. 2). AUDPC for spring-applied ethofumesate plots was significantly greater than that for fallapplied and nontreated control plots that were treated with flutolanil, iprodione, propiconazole, or no fungicide; however, there were no significant differences between fall-applied and nontreated control plots that were treated with these fungicides. There were no significant differences among the AUDPCs for ethofumesate-treated plots in fall or spring and the nontreated control plots that were treated with thiophanate-methyl, chlorothalonil, azoxystrobin.

\section{DISCUSSION}

Annual bluegrass is a serious weed in golf course fairways because of its aggressive growth habit. It is not affected by gray leaf spot, and proliferates rapidly by establishing in the bare areas resulting from gray leaf spot epidemics in perennial ryegrass. Chemical control of annual bluegrass in fairways is a major component of annual bluegrass management strategy, and is achieved mainly by application of ethofumesate. The herbicide generally is applied in fall in most regions of the United States; however, it also is applied in spring on many golf courses where infestation by annual bluegrass is severe. In some cases, application of ethofumesate is extended up to 30 days after annual bluegrass emergence in late spring, as recommended by the label in established perennial ryegrass turf. Currently, new approaches are being considered in the turfgrass industry for split application of ethofumesate throughout the growing season for sustained suppression of annual bluegrass seedhead production. Although such practice is not recommended by the manufacturer, it may become widespread in the golf course industry once a revised label becomes available in the industry.

Undesired effects of herbicide applications include adverse effects on growth and development of nontarget crops, potential increases in pathogen population, and severity of various diseases of crop plants. Such effects have been clearly demonstrated in several plant species, particularly in field crops $(1,2,4,5,13,18,22$, $23,31)$. However, these effects have not been widely reported in the turfgrass pathosystem. Effects of ethofumesate on turfgrasses have been tested primarily on plant species tolerant to the herbicide. Studies have shown that ethofumesate is suppressive to several nontarget turfgrass species such as Bermudagrass (7,19,21,27), Kentucky bluegrass (30), fescues (11), and zoysiagrass (20). Injury of perennial ryegrass by ethofumesate, as indicated by visual assessment of plants, reportedly is less significant under the conditions in the southern regions of the United States (7) and in Europe (8), and such effects appear to be even less evident in turf grown in the mid-Atlantic region of the United States. (12).

The present study was conducted in the southeastern region of Pennsylvania, which has a history of serious gray leaf spot epidemics. Ethofumesate is widely used for control of annual bluegrass in this region, and there has been no reported injury of perennial ryegrass by application of the herbicide either in fall or spring. It was important that effects of herbicide application timing be evaluated under application regimes of various classes of fungicide that have different levels of efficacy for gray leaf spot. This allowed us to achieve relatively high and low disease severity. Additionally, evaluation of the effects of herbicide application timing under typical field conditions in golf courses was critical. For example, systemic fungicides such as thiophanate-methyl and azoxystrobin and the contact fungicide chlorothalonil are widely used for control of gray leaf spot because of their high efficacy. Similarly, flutolanil commonly is used for control of brown patch and is ineffective for gray leaf spot. Propiconazole, iprodione, and chlorothalonil are broad-spectrum fungicides of relatively low cost and are used for control of various diseases, particularly in low-budget operations. Propiconazole has low to moderate and iprodione has no efficacy for gray leaf spot $(10,32,36,42)$.

The results of this study show that the effects of timing of ethofumesate application on severity of gray leaf spot varied with fungicide regime. The effects of timing of ethofumesate application was more pronounced when disease pressure was moderate to high. Significantly greater disease severity was observed in turf that received the herbicide in spring compared with turf that received the herbicide in fall in combination with low to moderately effective fungicides such as flutolanil and propiconazole. This indicates that spring application of ethofumesate can enhance gray leaf spot during the following summer, particularly when turf managers maintain a fairway spray program that includes flutolanil and propiconazole, designed for control of brown patch and dollar spot, respectively. Although the label recommends that ethofumesate can
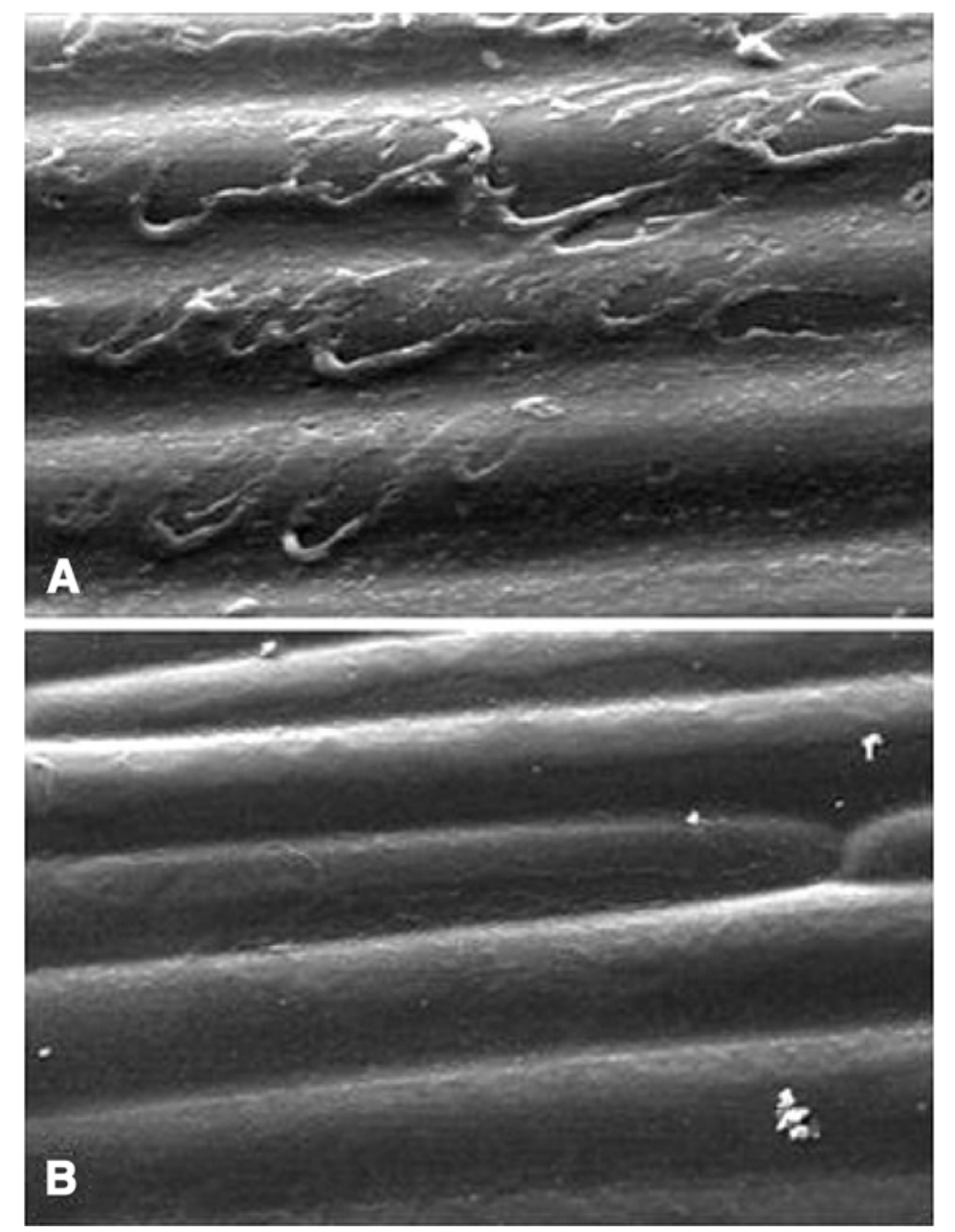

Fig. 4. Effect of ethofumesate on epicuticular wax deposition on perennial ryegrass leaf blade. A, Cryoscanning electron micrograph of perennial ryegrass leaf blade 4 weeks after treatment with ethofumesate, and $\mathbf{B}$, control (distilled water). 
be applied in fall and spring, turf managers should avoid spring application in fairways with a history of severe gray leaf spot problems. Turf managers who rely on broadspectrum fungicides with low to no efficacy for gray leaf spot for their summer spray program also should avoid spring application of the herbicide. In fairways where annual bluegrass infestation and seed production may be high, an alternative weed control method such as spot treatment of large patches of annual bluegrass should be employed. In this study, it was evident that the effect of ethofumesate on gray leaf spot severity was not significant for fall application treatment, probably because the herbicide had dissipated in plant tissue and in soil during the period of vigorous turf growth in the following spring. Hot and dry conditions during the summer are less favorable to the growth of perennial ryegrass; therefore, longevity of the herbicide in plant tissue is likely to be greater. Additionally, there is a much shorter period of time between spring application and gray leaf spot development in late summer.

Although there is little or no visual effect of ethofumesate on perennial ryegrass plants $(7,8,12)$, there are significant physiological effects of ethofumesate resulting in increased chlorophyll and nitrogen content in perennial ryegrass tissue (8). Further, ethofumesate interferes with fatty acid biosynthesis in plants that results in thinning of epicuticular wax $(14,16)$. Application of ethofumesate on cabbage leaves appeared to remove the epicuticular wax (25). Thinning and aggregation of epicutitular wax also has been observed on perennial ryegrass leaf blades 6 weeks after the application of ethofumesate to perennial ryegrass in the greenhouse (Fig. 4; W. Uddin and M. D. Soika, unpublished). Such effects may have contributed to the increased severity of gray leaf spot in turf that was treated with ethofumesate in spring. Successful infection by Pyricularia grisea largely depends on appressoria formation and successful penetration by a penetration peg (17). It is possible that the thinning and aggregation of epicuticular wax could have enhanced the ingress and also increased the number of infection foci by $P$. grisea on individual leaf tissue, thus contributing to the increase of gray leaf spot severity.

This is the first documentation of the influence of ethofumesate on gray leaf spot epidemic development. Because of the heavy reliance on use of ethofumesate for management of annual bluegrass, the herbicide is likely to remain an important tool in turfgrass cultural management. Further studies on the effects of the rate and frequency of application of ethofumesate on established perennial ryegrass turf as well as on newly seeded or overseeded turf will contribute further to understanding of the role of the herbicide in gray leaf spot disease development.

\section{ACKNOWLEDGMENTS}

We thank J. Nairn, the superintendent of Willow Hollow Golf Course, for providing the turf areas for this study; and F. Moorman, J. Shelton, and E. Soika for their assistance in conducting the experiments.

\section{LITERATURE CITED}

1. Altman, J., and Ross, M. 1967. Plant pathogens as a possible factor in unexpected preplant herbicide damage in sugar beets. Plant Dis. Rep. 51:86-88.

2. Altman, J., and Rovira, A. D. 1989. Herbicidepathogen interactions in soil-borne root diseases. Can. J. Plant Pathol. 11:166-172.

3. Bain, D. C., Patel, B. M., and Patel, M. V. 1972. Blast of ryegrass in Mississippi. Plant Dis. Rep. 56:210.

4. Campbell, C. L., and Altman, J. 1977. Pesticide plant disease interactions: Effect of cycloate on growth of Rhizoctonia solani. Phytopathology 67:557-560.

5. Canaday, C. H., Helsel, D. G., and Wyllie, T. D. 1986. Effects of herbicide induced stress on root colonization of soybeans by Macrophomina phaseolina. Plant Dis. 70:863-866.

6. Carver, R. B., Rush, M., and Lindberg, G. D. 1972. An epiphytotic of ryegrass blast in Louisiana. Plant Dis. Rep. 56:157-159.

7. Coats, G. E., and Krans, J. V. 1986. Evaluation of annual bluegrass (Poa annua) and turfgrass tolerance. Weed Sci. 34:930-935.

8. Dean, M. R. Ollerenshaw, J. H., and Stewart, W. S. 1987. The influence of ethofumesate on the growth and development, chlorophyll and nitrogen content of Lolium perenne L. Grass Forage Sci. 42:225-232.

9. Dernoeden, P. H. 1996. Perennial ryegrass and gray leaf spot. Golf Course Manage. 64:49-52.

10. Dernoeden, P. H. 1999. Gray leaf spot control with fungicides, 1998. Fungic. Nematicide Tests 56:T32.

11. Dernoeden, P. H. 2000. Tolerance of four Festuca species to ethofumesate and prodiamine. HortScience 35:1170-1173.

12. Dernoeden, P. H., and Turner, T. R. 1988. Annual bluegrass control and tolerance of Kentucky bluegrass and perennial ryegrass to ethofumesate. HortScience 23:565-567.

13. Descalzo, R. C., Punja, Z. K., Levesque, C. A., and Rahe, J. E. 1998. Glyphosate treatment of bean seedlings causes short-term increases in Pythium populations and damping off potential in soils. Appl. Soil Ecol. 8:25-33.

14. Devine, M. D. Duke, S. O., and Fedtke, C. 1993. Pages 225-242 in: Physiology of Herbicide Action. Prentice Hall, Englewood Cliff, NJ.

15. Harmon, P., Rane, K., Ruhl, G., and Latin, R. 2000. First report of gray leaf spot on perennial ryegrass in Indiana. Plant Dis. 84:492.

16. Harwood, J. L. 1991. Herbicides affecting chloroplast lipid synthesis. Pages 209-243 in: Herbicides. N. R. Baker and M. P. Percival, eds. Elsevier Science Publishers, New York.

17. Howard, R. J. 1994. Cell biology of pathogenesis. Pages 3-22 in: Rice Blast Disease. R. S. Zeigler, S. A. Leong, and P. S. Teng, eds. CAB International, Wallingford, UK.

18. Johal, G. S., and Rahe, J. E. 1984. Effects of soilborne plant pathogenic fungi on the herbicidal action of glyphosate on bean seedlings. Phytopathology 74:950-955.

19. Johnson, B. J. 1986. Response to vertical mowing and ethofumesate treatments for annual bluegrass control in Bermudagrass turf. Agron. J. 78:495-498.

20. Johnson, B. J. 1992. Common Bermudagrass (Cynodon dactylon) suppression in Zoysia spp. with herbicides. Weed Technol. 6:813-819.

21. Johnson, B. J., and Duncan, R. R. 2000. Timing and frequency of ethofumesate plus flurprimidol treatments on Bermudagrass (Cynodon spp.) suppression in seashore paspalum (Paspalum vaginatum). Weed Technol. 14:675-685.
22. Kawate, M. K., Kawate, S. C., Ogg, A. G., and Kraft, J. M. 1992. Response of Fusarium solani f. sp. pisi and Pythium ultimum to glyphosate. Weed Sci. 40:497-502.

23. Kerr, G. W., Gudauskas, R. T., and Dickens, R. 1977. Effects of three herbicides on selected pathogens and diseases of turfgrasses. Phytopathology 69:279-282.

24. Landschoot, P. J., and Hoyland, B. F. 1992. Gray leaf spot of perennial ryegrass turf in Pennsylvania. Plant Dis. 76:1280-1282.

25. Leavitt, J. R. C., Duncan, D. N., Penner, D. and Meggitt, W. F. 1978. Inhibition of epicuticular wax deposition on cabbage by ethofumesate. Plant Physiol. 61:1034-1036.

26. McCarty, B. 2000. Perennial ryegrass on golf courses: friend or foe? Grounds Maint. January 67-74.

27. McCarty, L. B. 1996. Selective control of Bermudagrass in St. Augustinegrass. Crop Sci. 36:694-698.

28. Pedersen, D. K., Kane, R. T., and Wilkinson, H. T. 2000. First report of gray leaf spot caused by Pyricularia grisea on Lolium perenne in Illinois. Plant Dis. 84:1151.

29. Schumann, G. L. 1999. First report of gray leaf spot (Pyricularia grisea) on perennial ryegrass (Lolium perenne) in New England. Plant Dis. 83:1073.

30. Shearman, R. C. 1986. Kentucky bluegrass and annual bluegrass response to ethofumesate. HortScience 21:1157-1159.

31. Smiley, R. W., Ogg, A. G., and Cook, R. J. 1991. Influence of glyphosate on Rhizoctonia root rot, growth, and yield of barley. Plant Dis. 76:937-942

32. Towers, G. W., Majumdar, P. R., Weibel, E DiMarco, J. N, Peacos, M,. and Clarke. B. B. 2000. Efficacy of fungicides for control of gray leaf spot on perennial ryegrass, 1999. Fungic. Nematicide Tests 55:520.

33. Trevathan, L. E., Moss. M. A., and Blasingame, D. 1994. Ryegrass Blast. Plant Dis. 78:113-117

34. Uddin, W., Schumann, G. L., Viji, G., and Boyd, S. H. 2000. Monitoring gray leaf spot epidemics in golf courses in New England, New Jersey, and Pennsylvania in 2000. (Abstr.) Phytopathology 91:S198.

35. Uddin, W., Serlemitsos, K., and Viji, G. 2003. A temperature and leaf wetness duration-based model for prediction of gray leaf spot of perennial ryegrass turf. Phytopathology 93:336-343.

36. Uddin, W., and Shelton, J. 2002. Evaluation of fungicides for control of gray leaf spot on perennial ryegrass, 2001. Fungic. Nematicide Tests 57:T34.

37. Uddin, W., Soika, M. D., Shelton, J., and Soika, E. L. 2001. Severity of gray leaf spot (blast) of perennial ryegrass turf as influenced by nitrogen source. (Abstr.) Phytopathology 91:S90.

38. Uddin, W., Viji, G., and Stowell, L. 2002. First report of gray leaf spot of perennial ryegrass in sports field in California. Plant Dis. 86:75.

39. Uddin, W., Viji, G., and Vincelli, P. 2003. Gray leaf spot (blast) of perennial ryegrass turf: An emerging problem for the turfgrass industry. Plant Dis. 87:880-889.

40. Vaiciunas, S., and Clarke, B. B. 2000. Impact of cultural practices and genotype on the development of gray leaf spot in cool season turfgrasses. Proc. Rutgers Turfgrass Symp. New Brunswick, NJ.

41. Vincelli, P., and Dixon, E. 2002. Resistance to $\mathrm{Q}_{\mathrm{o}} \mathrm{I}$ (Strobilurin-like) fungicide in isolates of Pyricularia grisea from perennial ryegrass. Plant Dis. 86:235-240.

42. Watkins, J. E., and Wit L. A. 2001. Fungicides evaluated for control of gray leaf spot, 2000 Fungic. Nematicide Tests 56:T35.

43. Williams, D. W., Burrus, P. B., and Vincelli, P. 2001. Severity of gray leaf spot in perennial ryegrass as influenced by mowing height and nitrogen level. Crop Sci. 41:1207-1211. 